\title{
Failure Risk for Frame Buildings by Certification Results: Probability Assessment
}

\author{
Vladimir Lapin*, Erken Aldakhov, Syrymgaly Erzhanov, Seric Aldakhov \\ JSC Kazakh Research and Design Institute of Construction and Architecture, 050043, Almaty, 21 Solodovnikova, Kazakhstan
}

Received September 30, 2021; Revised October 26, 2021; Accepted December 1, 2021

\section{Cite This Paper in the following Citation Styles}

(a): [1] Vladimir Lapin, Erken Aldakhov, Syrymgaly Erzhanov, Seric Aldakhov, "Failure Risk for Frame Buildings by Certification Results: Probability Assessment," Civil Engineering and Architecture, Vol. 9, No. 7, pp. 2389 - 2396, 2021. DOI: $10.13189 /$ cea.2021.090725.

(b): Vladimir Lapin, Erken Aldakhov, Syrymgaly Erzhanov, Seric Aldakhov (2021). Failure Risk for Frame Buildings by Certification Results: Probability Assessment. Civil Engineering and Architecture, 9(7), 2389 - 2396. DOI: 10.13189/cea.2021.090725.

Copyright $(\mathrm{C} 2021$ by authors, all rights reserved. Authors agree that this article remains permanently open access under the terms of the Creative Commons Attribution License 4.0 International License

\begin{abstract}
In many situations, the level of safety is established by following the guidelines set forth in rules or regulations. Engineers are accountable for giving quantitative estimates for different factors, particularly failure cost, when extra information is available, such as the owner's needs. By order of the Akimat of the city of Almaty, within 2017-2018, for the first time, a full certification of the housing stock of apartment buildings was carried out. 1847 multi-story frame buildings of various stories entered into the database. Based on the certification results, for the first time, quantitative estimates of the values of the probability of failure and reliability were obtained for frame buildings of various types. The recurrence of earthquakes is taken into account by the current "Seismic zoning map of the Republic of Kazakhstan." The results of assessments of the values of reliability and failure are used for practical recommendations on reducing the risk and expected losses in case of possible earthquakes. A total reinforcement of frame buildings with a first flexible floor ( 59 buildings) is proposed. The method of amplification should be determined by special research.
\end{abstract}

Keywords Certification, Risk, Frame Building, Frame-Brick Building, Reliability, Repeatability

\section{Introduction}

Seismic codes were devised and refined as a result of large earthquakes that wreaked havoc in densely populated areas. These are often changed depending on new information obtained from previous earthquakes and study discoveries, and as a result, they are always changing. Seismic codes are used all around the world. Most codes have similar fundamental approaches on how to design structures for earthquake impacts at their core, but they will differ in technical requirements and include language addressing local geology circumstances, common construction types, historical difficulties, etc. Simply put, seismic zones are areas on a map where earthquakes have historically occurred in clusters. Seismologists commonly use the phrase seismic zone to refer to locations where seismicity is believed to be caused by the same source [Sippl et al., 2019]. Seismic zones are defined as areas on a map with a similar areal rate of seismicity for the purposes of computing probabilistic ground movements for seismic hazard assessment [Florez \& Prieto, 2019; Sil et al., 2013]. The megapolis area of the city of Almaty is the most highly seismic zone in Central Asia. The city is home to over 2 million people, with the prospect of population growth to 5 million by 2035 . Over the past 140 years, there have been three strong earthquakes with magnitudes 7-8 Vernenskoe in 1887, Chilikskoe in 1889, and Kebinskoe (Keminskoe) in 1911. In these conditions, the seismic safety of the population must be ensured.

The use of frame buildings in seismic areas is due to their good resistance to seismic effects during earthquakes. It was found that if frame buildings are designed in 
compliance with the principles of earthquake-resistant construction, then the earthquake resistance of such buildings is beyond doubt [Akbari \& Ayubirad, 2017; Ayubi Rad \& Ayubirad, 2017; Chen et al., 2019; Hinarejos et al., 2018; Karmenova et al., 2020; Ontiveros-Perez et al., 2019]. The CBF (concentrically braced frame) is a typical and effective seismic force-resisting technology used in low-rise buildings. Steel braces are used in this sort of structural structure to give the rigidity and strength needed to disperse seismic energy. Various bracing arrangements have been recommended in various building regulations throughout the world. These rules include specific design criteria for structural elements and connections but no advice on how to choose the optimum bracing arrangement for the project [Mitasov et al., 2019; Nemchinov, 2008; Silacheva et al., 2020; Tulaganov, 2021].

In the city of Almaty, there is a fairly large number of frame buildings that have been erected in the last 30-35 years. These are five-story frame residential buildings of the standard series 70s, VT, VP-1, as well as nine-story frame residential buildings, erected according to the standard series SZhKU-9.

In almost all frame buildings, prefabricated floors of reinforced concrete slabs with voids and monolithic reinforced concrete straps were used [Babiy et al., 2018; Butska et al., 2019; Dovzhenko \& Pohribnyi, 2019; Mailyan \& Del Socorro, 2020; Mukhametrakhimov et al., 2021]. Brick was mainly used as enclosing structures in buildings with a height of up to five floors and hinged prefabricated lightweight aggregate concrete panels with a height of more than five floors [Osuská \& Hela, 2020; Rahman \& Uddin, 2018]. The height of residential frame buildings varies from 4 to 9 floors.

In addition to these structural types, the construction of the city of Almaty also includes frame buildings with a first flexible floor, diaphragms and stiffening cores, and various kinds of girderless systems. In modern multi-story structures, a soft first story is a common characteristic. Despite the fact that multi-story structures with soft story floors are inherently prone to earthquake collapse, they are nevertheless common in developing countries. The functional and social necessity for ground-level vehicle parking and open-story workplaces at various levels of the structure significantly outweighs the technical community's warnings against such structures [Dolšek \& Fajfar, 2001; Halde \& Deshmukh, 2015; Khandve, 2012; Ko \& Lee, 2006].

Buildings with a first flexible floor are highly vulnerable to earthquakes. The main reason for the destruction of such buildings is the loss of stability of the struts due to large displacements during strong seismic events.

In 2017-2018, in the city of Almaty, a total certification of the multi-apartment housing stock was carried out, as a result of which electronic passports of the surveyed buildings were created. Below are the assessments of the reliability and risk of such buildings using the results of certification. Quantitative data on assessments of failure and reliability of frame buildings for the city of Almaty were obtained for the first time.

\section{Materials and Methods}

\subsection{Multi Apartment 5-Story Frame-Brick Residential Buildings of the 70s Series}

Residential buildings of the 70c series, according to the structural system, refer to buildings with a precast-monolithic reinforced concrete frame-braced frame. The cross-sectional dimensions of the columns are $50 \times 30 \mathrm{~cm}$. The cross-sectional dimensions of the longitudinal girders are $40 \quad x \quad 50 \quad$ (h) $\quad \mathrm{cm}$. The cross-sectional dimensions of the transverse girders are 50 x $22(\mathrm{~h}) \mathrm{cm}$. The concrete class of monolithic reinforced concrete columns and girders is B25.

Stiffening diaphragms in the basement level - precast reinforced concrete $160 \mathrm{~mm}$ thick. Concrete class of stiffness diaphragms B20. Stiffness diaphragms at the level of the 1st to 5th floors are prefabricated expanded clay concrete with a thickness of $160 \mathrm{~mm}$. Concrete class of stiffness diaphragms B20. There are no crossbars and stiffening diaphragms at the technical floor level. Stiffening diaphragms are connected to columns and girders using monolithic reinforced concrete infills.

Basement and floor slabs are prefabricated from prestressed panels with round voids. The covering is precast from prestressed ribbed panels. Floor panels and coverings are laid on the crossbars of the longitudinal frames.

The outer walls are made of brick, self-supporting, 51 $\mathrm{cm}$ thick, lined along the inner facade with cement-sand slabs and shell rock slabs along the outer facade. Partitions - precast from large-sized rolled gypsum concrete panels and brick.

The roof is soft combined with an internal drain.

Foundations: for columns - monolithic reinforced concrete, free-standing columnar, for stiffening diaphragms - monolithic reinforced concrete tape. Foundation concrete class B20.

\subsection{Multi Apartment 5-Story Frame-Brick Residential Buildings of the VP-1 And VT Series}

According to the structural system, residential buildings of the VP-1 and VT series belong to buildings with a precast-monolithic reinforced concrete frame carcass (a grid of columns $3.5 \times 5.4 \mathrm{~m}$ and $4.0 \times 6.0 \mathrm{~m}$, respectively). Frame columns in these series are made of monolithic reinforced concrete, and crossbars are made of precast concrete. All connections of frame elements are made by 
brazing of reinforcement outlets in the nodes, followed by their concreting.

The carried-out studies have shown that in real conditions, the quality of the brazing and the strength of the concrete for embedding the units do not always meet the requirements of the project, and some buildings of this type (having an unsatisfactory construction quality) cannot be considered as earthquake resistant. At the same time, in general, the frame buildings of these series can be classified as seismic safety since they can withstand seismic effects without damage and destruction, which pose a direct threat to the safety of people.

\subsection{Multi-Apartment 9-Story Frame Residential Buildings of the SZhKU-9 Series}

Residential buildings of the SZhKU-9 series, according to the structural system, refer to buildings with a prefabricated reinforced concrete frame space carcass. Frame structures of the carcass are located in the longitudinal and transverse directions of the building. The load-bearing structures are transverse frames made of prefabricated reinforced concrete enlarged Zh-shaped half-frames with tier cutting of columns in the areas of least effort from horizontal seismic forces; the girder joints in the middle span are made by welding metal plates ("fish") to metal girder heads.

In the longitudinal direction, the transverse frames are connected by crossbars of the longitudinal frames. The joints of the columns and crossbars of the longitudinal frames are made by welding overlays ("fish") welded to the metalheads of the consoles of the columns and crossbars.

\section{Results}

\subsection{The Results of Certification}

Table 1 shows the results of certification for the group of frame buildings. Frame-brick buildings with a first flexible floor are not earthquake resistant here. This is $4 \%$ of the total number of frame buildings. Therefore, the group of frame buildings as a whole complies with the norms of earthquake-resistant construction and seems to be safe enough for living.

It should be noted that four frame-brick buildings are seismically isolated using a seismic isolation system using kinematic foundations.
Table 1. Multi-apartment frame residential buildings by series.

\begin{tabular}{|c|c|c|c|c|}
\hline № & $\begin{array}{c}\text { Series of } \\
\text { frame } \\
\text { buildings }\end{array}$ & $\begin{array}{c}\text { Number } \\
\text { of } \\
\text { buildings }\end{array}$ & $\begin{array}{c}\text { Earthquake } \\
\text { resistant } \\
\text { buildings }\end{array}$ & $\begin{array}{c}\text { Non-earthquake } \\
\text { resistant } \\
\text { buildings - } \\
\text { buildings with a } \\
\text { first flexible } \\
\text { floor. }\end{array}$ \\
\hline 1 & VP & 575 & 562 & 13 \\
\hline 2 & BT & 235 & 224 & 11 \\
\hline 3 & $70 S$ & 18 & 18 & 32 \\
\hline 4 & IPcar & 1006 & 974 & 3 \\
\hline 5 & SZhKU-9 & 13 & 10 & 59 \\
\hline & Total & 1847 & 1788 & - \\
\hline
\end{tabular}

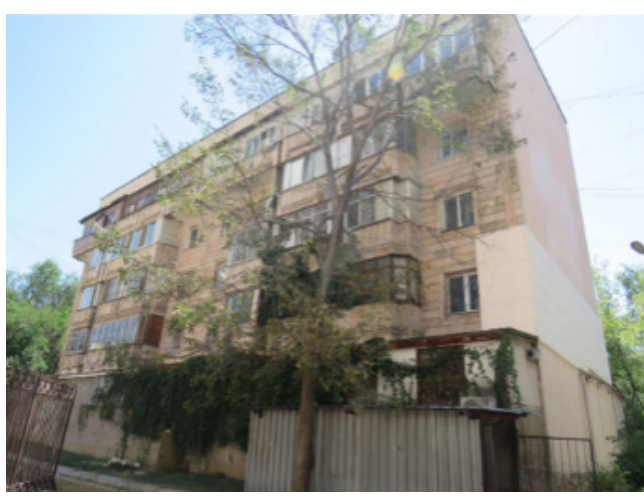

Figure 1. Furmanova, st., house 229, 70 series

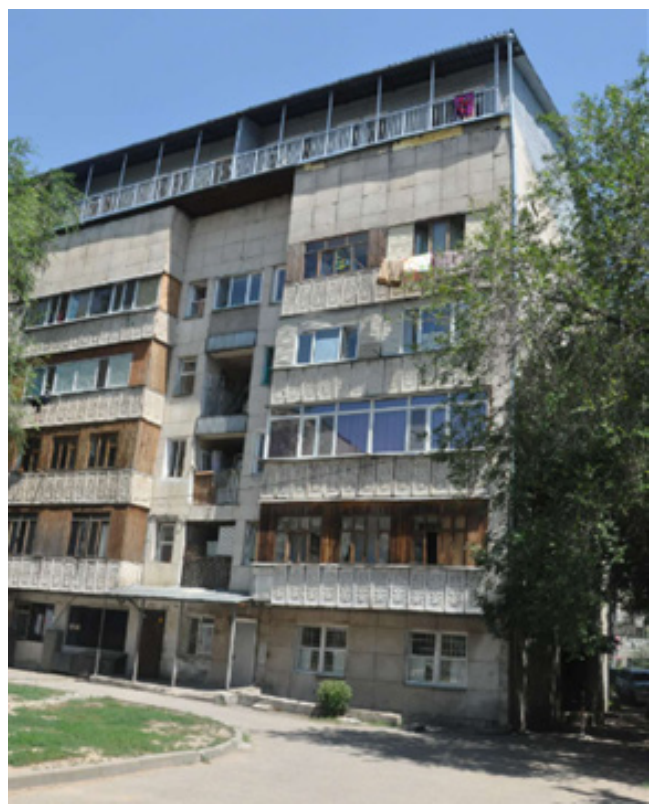

Figure 2. Baizakova, st., house 263, 70 series 


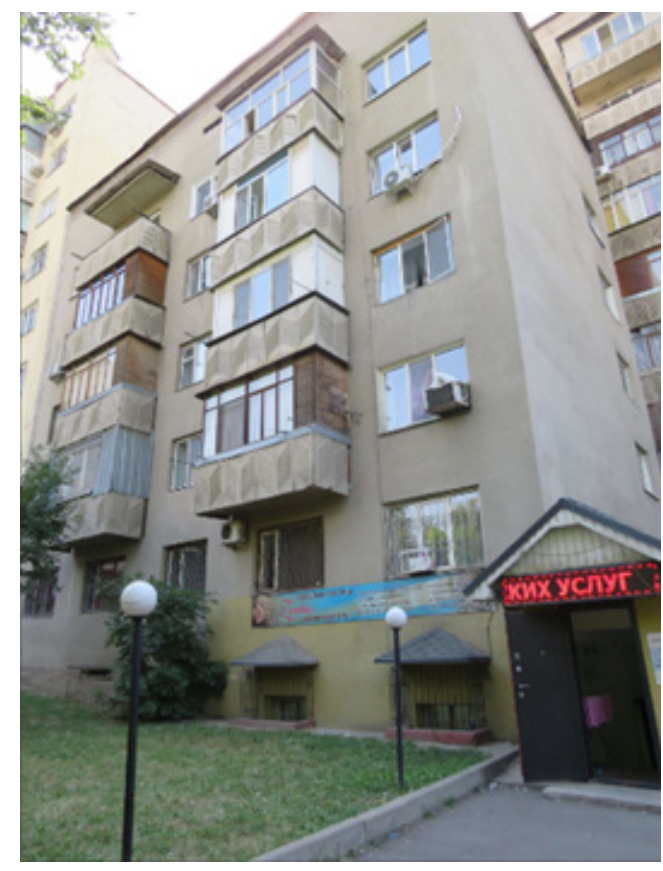

Figure 3. Md. Mamyr-7, building 11, VP

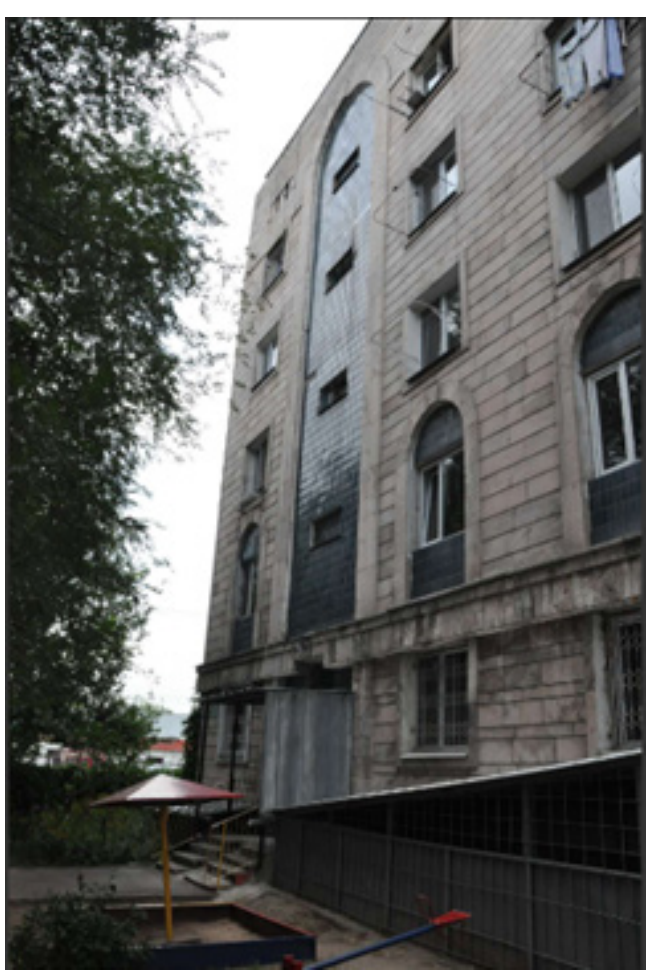

Figure 4. Emtsova, st., house 8/2, IPcar

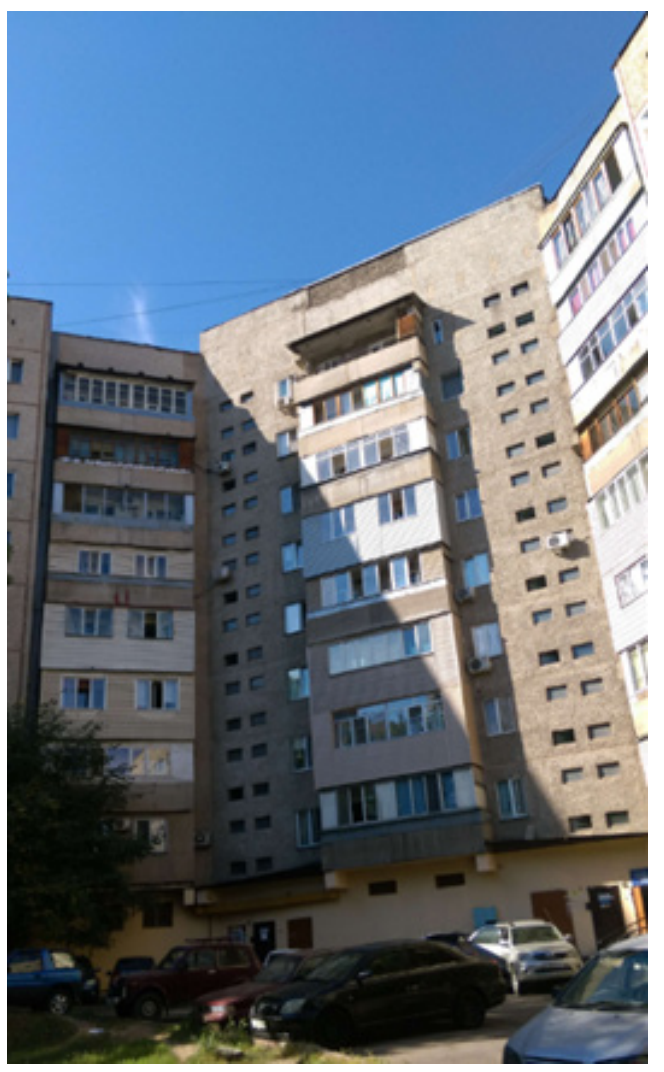

Figure 5. Rozybakiyeva, St., house 140, SZhKU-9

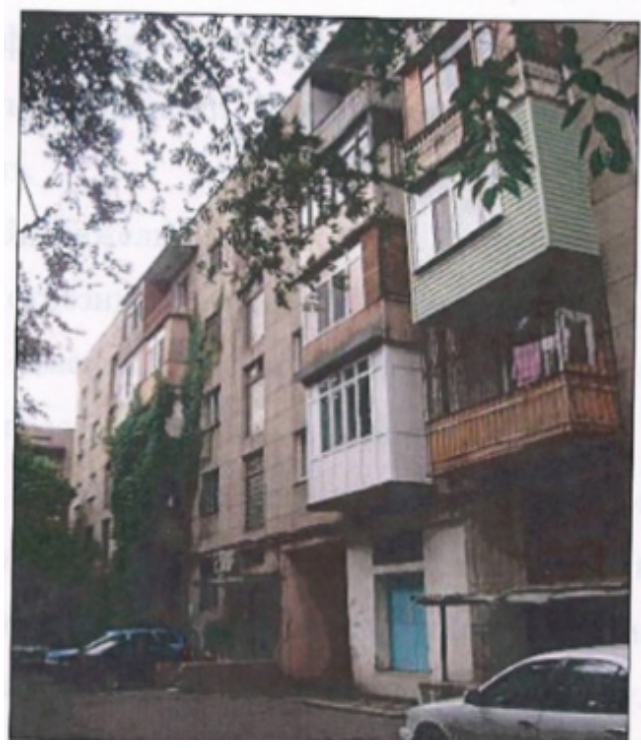

Figure 6. Furmanova, st., house 57 


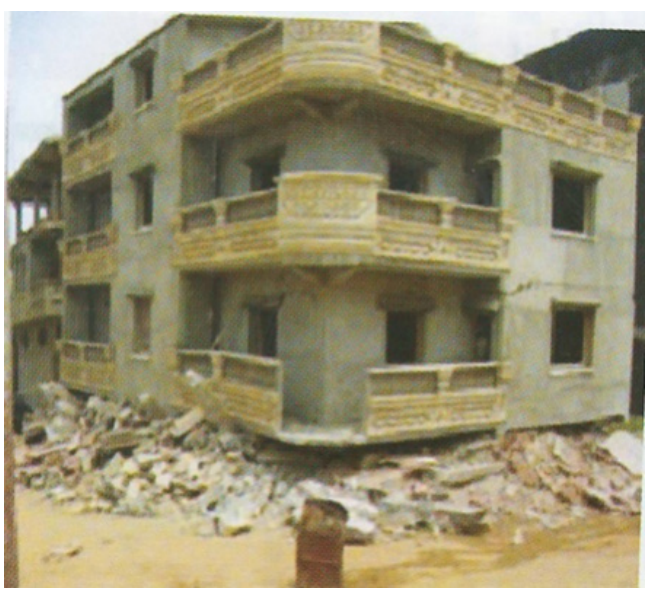

Figure 7. Destruction of a building with a flexible first floor during the earthquake in Boumerdes (Algeria, 2003) [Nemchinov, 2008]

\subsection{Experimental Data On Dynamic Characteristics}

JSC "KazNIISA" has a network of engineering and seismometric stations on buildings located on frame buildings in Almaty. Table 2 shows the dynamic characteristics of frame buildings (periods of vibration in the transverse and longitudinal axes).

The dynamic characteristics of these buildings were determined from instrumental records of earthquakes. The oscillation period values can be used to determine seismic loads or to designate a method for strengthening buildings after an earthquake.

\section{Discussion}

The name of the approach is since phenomenology considers a specific experience and tries to describe it, as much as possible, with minimal distortions or interpretations.

As a hypothesis, we will consider the results above to be true and obtained when the following failure criterion is implemented. Failure $Q$ here is an event consisting of the fact that during an earthquake with an intensity of 9 points, the degree of damage to the object will be such that its further functioning will be excluded. The assignment of a building to the class of non-earthquake resistance is carried out by a group of experts who assign it to the specified class based on previous experience and objective information.

Let us assume that the conditional probabilities of failures at the indicated acceleration values are the same, i.e., earthquake-resistant buildings are the same at acceleration values specified in regulatory documents. A scheme or an earthquake is realized with a repeatability of 1 time in 475 years or 1 time in 2475 years. The building service life is assumed to be 50 years. The last row of Table 3 shows the total failure probabilities for all frame buildings $Q_{475}=0,03485$ and $Q_{2475}=0,00671$.

Table 2. Dynamic characteristics of frame buildings according to the data of engineering and seismometric stations (sec).

\begin{tabular}{|c|c|c|c|}
\hline No & Station number and name & $\begin{array}{c}\text { Earthquake } \\
\mathbf{0 3 / 2 5 / 1 9 7 8}\end{array}$ & $\begin{array}{c}\text { Earthquake, } \\
\mathbf{0 5 / 3 1 / 2 0 1 2}\end{array}$ \\
\hline 1 & $\begin{array}{c}\text { Station 1 } \\
\text { "INSTITUTE", }\end{array}$ & 0,$5 ; 0,42$ & 0,$46 ; 0,51$ \\
\hline 2 & 4-story precast reinforced concrete frame & & 0,$39 ; 0,44$ \\
\hline $\begin{array}{c}\text { Station 3 } \\
\text { "SCHOOL", }\end{array}$ & 0,$48 ; 0,55$ & - \\
\hline 3 & $\begin{array}{c}\text { 4-story precast reinforced concrete frame with prefabricated reinforced } \\
\text { concrete floors with external expanded clay concrete panels }\end{array}$ & 0,$6 ; 0,64$ & 0,$35 ; 0,36$ \\
\hline 4
\end{tabular}

Table 3. Characteristics of the probability of failure $Q$ for frame buildings.

\begin{tabular}{|c|c|c|c|c|}
\hline № & Constructive solution & $\begin{array}{c}\text { Failure rate by type of } \\
\text { frame buildings }\end{array}$ & $\begin{array}{c}\text { Failure values with } \\
\text { repeatability of 475 years }\end{array}$ & $\begin{array}{c}\text { The failure rate with } \\
\text { repeatability of 2475 years }\end{array}$ \\
\hline 1 & VP & 0,0226 & 0,00237 & 0,00046 \\
\hline 2 & VT & 0,0468 & 0,00491 & 0,00095 \\
\hline 3 & $70 \mathrm{~s}$ & 0 & 0 & 0 \\
\hline 4 & IPcar & 0,0319 & 0,00334 & 0,00064 \\
\hline 5 & SZhKU-9 & 0,2308 & 0,02423 & 0,00466 \\
\hline & All types & & 0,03485 & 0,00671 \\
\hline
\end{tabular}


Then the total value is $Q_{\text {car }}=\mathrm{Q}_{9} P_{475}+Q_{9} P_{2475}$.

Then the value of the overall reliability for the group of frame residential buildings is

$$
\mathrm{W}_{\text {car }}=1-0,03485-0,00671=0,95844
$$

The obtained value of the overall reliability $\mathrm{W}_{\text {car }}$ is an objective quantitative characteristic of the state of a group of frame multi-story residential buildings in Almaty, taking into account the recurrence of seismic impact. Further actions can change the indicated $\mathrm{W}_{\text {car }}$ value.

If we strengthen all buildings with the first flexible floor - 59 buildings, then in this case, for all types of frame buildings, the probability of failure is $Q_{9}=0$. Then the reliability for all groups of frame buildings is reliability $\mathrm{W}=1$.

It should be noted that the probability of failure can also be determined using other methods for determining the probability of failure and reliability [Ahmad et al., 2018; Bunea et al., 2017; Dolce et al., 2020; Dzhinchvelashvili et al., 2018; Fathi-Fazl et al., 2018; Ferrier \& Haque, 2003; Hare, 2019; Leonard et al., 2014; Liu \& Wang, 2018; Maio et al., 2020; Raizer, 2004; Takewaki et al., 2013], developed by domestic and foreign experts. In conclusion, it should be mentioned that in the city of Almaty, there are about four frame buildings on seismic-insulating kinematic foundations [Lapin et al., 2019]. In the future, you can use other seismic isolation systems [Ahmad et al., 2018; Bulat et al., 2018, 2019; Hare, 2019; Lapin et al., 2019].

\section{Conclusions}

With time, all buildings and materials deteriorate and are destroyed. The only thing that fluctuates is the rate at which the deterioration occurs. A sandcastle on the beach could last for a few hours, but it could take billions of years for a mountain to crumble. When it comes to building construction, it's critical that it's constructed to last the specified amount of time. The structure should have a high degree of safety during its expected lifetime to withstand the pressures and stresses it is subjected to, as well as the environment to which it is exposed. Many forces are at work to deteriorate and destroy building structures. These degrading variables are often classified into three groups: loads, environment, and use. Because use frequently includes loads, this divide is not entirely rational, but it has practical advantages in the context of constructing structures. The impact of the environment on the structure of a building is inescapable. Corrosion in steel is perhaps the most frequent environmental stress, although all materials deteriorate in the environment in which they function, even if their lives can be exceptionally long. Other environmental stresses include a variety of chemical reactions as well as wind and water erosion. Humans who utilize the buildings contribute to an "environmental load," which is another term for "usage."
A building is, after all, designed to be utilized, which implies that it is susceptible to wear and tear in addition to the different stresses listed. The activities that take place within the structures wreak havoc on the structure. Protective paint is scraped away, blows and impacts wear material away, and minor but repetitive stresses produce small cracks, reducing the structure's strength over time. Our planet is subjected to a wide variety of unique natural loads, both intentional and unintentional. Here are a couple such instances. Earthquakes are the most obvious, but nature also provides many unexpected shocks, including volcanic eruptions, typhoons, floods, and meteorites. The likelihood of estimating such an incident can occur determines whether and to what extent a building should be constructed to resist such loads. The building is designed to withstand earthquake loads in locations where earthquakes are known to occur. Maps are created that indicate the predicted probabilities and magnitudes of such loads and the potential for ground dislocations. After conducting a study about the condition of frame buildings, it turned out:

1. Frame buildings with "first flexible floors" do not meet the requirements of the current standards and are earthquake-prone. Buildings with the first flexible floors require a detailed survey with a computational and analytical assessment of the bearing capacity of structures and the development of recommendations on the method of reinforcement;

2. Probabilistic assessments of the reliability of frame buildings have been obtained based on the results of certification both with and without earthquake frequency.

\section{Acknowledgment}

The research was carried out using the grant AP 05130702 of the Ministry of education and science of the Republic of Kazakhstan.

\section{REFERENCES}

[1] Ahmad, N., Ali, Q., Adil, M., \& Khan, A. N. (2018). Developing seismic risk prediction functions for structures. Shock and Vibration, 2018.

[2] Akbari, J., \& Ayubirad, M. S. (2017). Seismic optimum design of steel structures using gradient-based and genetic algorithm methods. International Journal of Civil Engineering, 15(2), 135-148.

[3] Ayubi Rad, M., \& Ayubirad, M. S. (2017). Comparison of artificial neural network and coupled simulated annealing based least square support vector regression models for prediction of compressive strength of high-performance concrete. Scientia Iranica, 24(2), 487-496.

[4] Babiy, I., Bichev, I., Zhayvoronok, D., \& Kolomiychuk, V. 
(2018). Research of lightweight monolithic reinforced concrete slabs with the use of plastic inserts. Вісник Одеської Державної Академії Будівниитва Та Архітектури, 71, 25-29.

[5] Bulat, A. F., Dyrda, V. I., Grebenyuk, S. N., \& Klimenko, M. I. (2019). Determination of effective characteristics of the fibrous viscoelastic composite with transversal and isotropic components. Strength of Materials, 51(2), 183192.

[6] Bulat, A. F., Dyrda, V. I., Lysytsya, M. I., \& Grebenyuk, S. M. (2018). Numerical simulation of the stress-strain state of thin-layer rubber-metal vibration absorber elements under nonlinear deformation. Strength of Materials, 50(3), 387395.

[7] Bunea, G., Doniga, C., \& Atanasiu, G. M. (2017). Study Concerning the Level of Seismic Risk in Iasi Municipality. Advanced Engineering Forum, 21, 86-93.

[8] Butska, O., Nikiforova, T., Makhinko, M., \& Shekhorkina, S. (2019). Investigating the strength and deformability of the node that connects precast slabs and monolithic joists in a flat precast-monolithic flooring slab. Восточно-Европейский Журнал Передовых Технологий, 4 (1), 14-25.

[9] Chen, P., Huang, Y., Mou, J., \& Van Gelder, P. (2019). Probabilistic risk analysis for ship-ship collision: State-of-the-art. Safety Science, 117, 108-122.

[10] Dolce, M., Prota, A., Borzi, B., da Porto, F., Lagomarsino, S., Magenes, G., Moroni, C., Penna, A., Polese, M., \& Speranza, E. (2020). Seismic risk assessment of residential buildings in Italy. Bulletin of Earthquake Engineering, 134 .

[11] Dolšek, M., \& Fajfar, P. (2001). Soft storey effects in uniformly infilled reinforced concrete frames. Journal of Earthquake Engineering, 5(01), 1-12.

[12] Dovzhenko, O., \& Pohribnyi, V. (2019). Improved Joints Of Reinforced Concrete Elements In Precast-And-Cast-In-Place Construction Based On Destruction Mechanics. Technology Transfer: Fundamental Principles and Innovative Technical Solutions, 58-60.

[13] Dzhinchvelashvili, G. A., Dzerzhinsky, R. I., \& Denisenkova, N. N. (2018). Quantitative assessment of seismic risk and energy concepts of earthquake engineering. Computer Research and Modeling, 10(1), 61-76.

[14] Fathi-Fazl, R., Jacques, E., Cai, Z., Kadhom, B., Saassouh, B., \& Motazedian, D. (2018). Development of a preliminary seismic risk screening tool for existing buildings in Canada. Canadian Journal of Civil Engineering, 45(9), 717-727.

[15] Ferrier, N., \& Haque, C. E. (2003). Hazards risk assessment methodology for emergency managers: A standardized framework for application. Natural Hazards, 28(2), 271290.

[16] Florez, M. A., \& Prieto, G. A. (2019). Controlling factors of seismicity and geometry in double seismic zones. Geophysical Research Letters, 46(8), 4174-4181.

[17] Halde, V. V., \& Deshmukh, A. H. (2015). Review on behavior of soft storey in building. International Research
Journal of Engineering and Technology (IRJET), 2(8).

[18] Hare, J. (2019). A different way of thinking about seismic risk. Bulletin of the New Zealand Society for Earthquake Engineering, 52(3), 141-149.

[19] Hinarejos, M. F., Almenárez, F., Cabarcos, P. A., Ferrer-Gomila, J. L., \& López, A. M. (2018). Risklaine: A probabilistic approach for assessing risk in certificate-based security. IEEE Transactions on Information Forensics and Security, 13(8), 1975-1988.

[20] Karmenova, M., Nugumanova, A., Tlebaldinova, A., Beldeubaev, A., Popova, G., \& Sedchenko, A. (2020). Seismic assessment of urban buildings using data mining methods. Proceedings of the 2020 6th International Conference on Computer and Technology Applications, 154-159.

[21] Khandve, A. V. (2012). Seismic Response of RC Frame Buildings with Soft Storeys. International Journal of Engineering Research and Applications (IJERA), 2(3), 2100-2108.

[22] Ko, D.-W., \& Lee, H.-S. (2006). Shaking table tests on a high-rise RC building model having torsional eccentricity in soft lower storeys. Earthquake Engineering \& Structural Dynamics, 35(11), 1425-1451.

[23] Lapin, V. A., Yerzhanov, S. E., \& Aldakhov, Y. S. (2019). Statistical modeling of a seismic isolation object under random seismic exposure. Journal of Physics: Conference Series, 1425(1), 012006.

[24] Leonard, M., Burbidge, D. R., Allen, T. I., Robinson, D. J., McPherson, A., Clark, D., \& Collins, C. D. N. (2014). The challenges of probabilistic seismic-hazard assessment in stable continental interiors: An Australian example. Bulletin of the Seismological Society of America, 104(6), 3008-3028.

[25] Liu, X.-X., \& Wang, Y.-S. (2018). A New Formulation on Seismic Risk Assessment for Reinforced Concrete Structures with Both Random and Bounded Uncertainties. Discrete Dynamics in Nature and Society, 2018.

[26] Mailyan, D. R., \& Del Socorro, V. A. L. (2020). Effective reinforced concrete structures of monolithic frame buildings and structures. IOP Conference Series: Materials Science and Engineering, 913(3), 032049.

[27] Maio, R., Estêvão, J. M., Ferreira, T. M., \& Vicente, R. (2020). Casting a new light on the seismic risk assessment of stone masonry buildings located within historic centres. Structures, 25, 578-592.

[28] Mitasov, V. M., Adischev, V. V., \& Logunova, M. A. (2019). A New Approach to Improving Seismic Safety Based on the Energy Theory of Reinforced Concrete Resistance. In Seismic Isolation, Structural Health Monitoring, and Performance Based Seismic Design in Earthquake Engineering (pp. 295-305). Springer.

[29] Mukhametrakhimov, R., Khuzin, A., \& Khamidullina, D. (2021). Quality improvement of monolithic steel fiber concrete floor slabs with void formers. E3S Web of Conferences, 274, 06001.

[30] Nemchinov, Y. (2008). Seismic resistance of buildings and structures. Kyiv, Hudymenko SV, 480. 
[31] Ontiveros-Perez, S. P., Miguel, L. F. F., \& Riera, J. D. (2019). Reliability-based optimum design of passive friction dampers in buildings in seismic regions. Engineering Structures, 190, 276-284.

[32] Osuská, L., \& Hela, R. (2020). The Impact of Different Aggregate Types and Its Composition on Resulting Concrete Properties Representing the Water Impermeability Level of Concrete for the Construction of White Boxes. Civil Engineering and Architecture, 8(2), 39-45. DOI: 10.13189/cea.2020.080201

[33] Rahman, S., \& Uddin, M. N. (2018). Experimental investigation of concrete with glass powder as partial replacement of cement. Civil Engineering and Architecture, 6(3), 149-154. DOI: 10.13189/cea.2018.060304

[34] Raizer, V. (2004). Theory of reliability in structural design. Appl. Mech. Rev., 57(1), 1-21.

[35] Sil, A., Sitharam, T. G., \& Kolathayar, S. (2013). Probabilistic seismic hazard analysis of Tripura and
Mizoram states. Natural Hazards, 68(2), 1089-1108.

[36] Silacheva, N. V., Kulbayeva, U. K., \& Kravchenko, N. A. (2020). On the realization of seismic microzonation of Almaty (Kazakhstan) in ground accelerations based on the "continual" approach. Geodesy and Geodynamics, 11(1), $56-63$.

[37] Sippl, C., Schurr, B., John, T., \& Hainzl, S. (2019). Filling the gap in a double seismic zone: Intraslab seismicity in Northern Chile. Lithos, 346, 105155.

[38] Takewaki, I., Moustafa, A., \& Fujita, K. (2013). Critical Characterization and Modeling of Pulse-Like Near-Field Strong Ground Motion. In Improving the Earthquake Resilience of Buildings (pp. 65-92). Springer.

[39] Tulaganov, B. A. (2021). Assessment of seismic vulnerability of buildings and structures by using European standards. Turkish Journal of Computer and Mathematics Education (TURCOMAT), 12(7), 323-330. 